\title{
Punning in Hungarian anti-proverbs
}

\author{
Katalin Vargha \\ Hungarian Academy of Sciences, Budapest, Hungary
}

\section{Anna T. Litovkina}

Tischner European University, Kracow, Poland

János Selye University, Komárno, Slovakia

\begin{abstract}
Proverbs have never been considered sacrosanct; on the contrary, they have frequently been used as satirical, ironic or humorous comments on a given situation. Wolfgang Mieder has coined the term "Antisprichwort" (anti-proverb) for such deliberate proverb innovations. There are a number of mechanisms of proverb variation (which are by no means mutually exclusive), e.g. adding a tail to the original text, replacing a single word, melting two proverbs, reversing word order, reversing sounds, and many others (on the most common types of alteration in Hungarian anti-proverbs, see Litovkina \& Vargha 2012). Anti-proverbs may contain revealing social comments, but they may also be based on mere wordplay or puns, and they may very often be just a product generated solely for the goal of deriving play forms. When translated from one language to another, an anti-proverb might lose its message: the puns, parodies or wordplay characteristic of one language will seldom carry over successfully into another. The present article focuses on one of the most popular techniques of proverb variation, punning. After treating the most frequent types of punning in Hungarian anti-proverbs (paronyms and homonyms), we will briefly consider some other types of puns (puns playing upon personal names, splitting of one word into two, merging of two words into one, bilingual puns, double/triple puns, and repetitive puns). The anti-proverbs discussed in this article were recorded by Anna T. Litovkina and Katalin Vargha and come from their corpus of over 7,000 Hungarian anti-proverbs.
\end{abstract}

Keywords: proverb, anti-proverb, punning. 


\section{What is a pun?}

A pun is defined by Webster's New Universal Unabridged Dictionary (1983: 1461) as "the humorous use of a word, or of words which are formed or sounded alike but have different meanings, in such a way as to play on two or more of the possible applications; a play on words". The unforeseen linking of different words, meanings or ideas creates the comic surprise characteristic of puns. Puns may give us much enjoyment and pleasure, probably as a result of what Freud (1960 [1905]: 25) called "an economy of expenditure" when we use one word which has two separate meanings, or when we slightly modify it.

According to Koestler (1964), the three types of creativity common to humanity (artistic originality, scientific discovery, and comic inspiration) are all based on bisociative thinking, and require a discovery of a relationship between one object or pattern and another object or pattern. "The logical pattern of the creative process is the same in all three cases; it consists in the discovery of hidden similarities" (Koestler 1964: 27). Bisociation is defined by Koestler as "...the perceiving of a situation or idea ... in two self-consistent but habitually incompatible frames of reference. ... The event ... in which the two intersect, is made to vibrate simultaneously on two different wavelengths, as it were. While this unusual situation lasts, [the event] is not merely linked to one associative context, but bisociated with two" (Koestler 1964: 35). In Koestler's view, "The pun is the bisociation of a single phonetic form with two meanings - two strings of thought tied together by an acoustic knot" (Koestler 1964: 64-65). Nilsen 1989: 399-400) calls punning "an aspect of a new scientific field - the science of chaos - a science that finds order in disorder".

Milner (1972: 16) states that "a very large number of phenomena that trigger off laughter can be shown to be due to reversal of one kind or another". Among items he examines are puns. Milner (1972: 16) argues that "within a single situation, and a single linguistic context, two universes collide, and it is this collision that makes many forms of humour possible". Later he develops this argument as follows:

Through the device of the pun, that is to say, in the widened sense in which it seems justifiable to use
this term, we are suddenly and forcibly made aware either (i) of an analytic relation of differential
meaning that separates things previously assumed to be alike, or (ii) of a syncretic relation of different
meaning that unites things previously assumed to be discrete. What sparks off laughter in us, that is to
say, is a differential gap ..., i.e., an awareness of an identity within the difference or of a difference
within the identity.

(Milner 1972: 18)

Attardo (1994), along with many other humour researchers, distinguishes four subcategories of puns: paronyms, homonyms, homographs and homophones:

Two words are paronyms when their phonemic representations are similar but not identical. Two words are homonyms when their phonemic or graphemic representation is identical, and two words are homographs when their graphemic representation is identical (i.e., they are spelled the same). Two words are homophones when their phonemic representation is identical (i.e., they are pronounced the same). Homographs and homophones are subclasses of homonyms.

(Attardo 1994: 110-111)

According to Esar (1952: 77), "the variety of puns must be infinite". He lists some puns according to category (e.g. repetitive, blending, divisive, additive, linking, etc.).

Hockett (1972: 157) talks about two categories of puns, "perfect" (identical in sound) and "imperfect" (nonidentical). Thus, according to his definition, homonyms and homophones could be called perfect puns, and paronyms and homographs, imperfect puns.

As was expected, the vast majority of puns in the corpus of Hungarian anti-proverbs are Open-access journal | EJHR: www.europeanjournalofhumour.org 
based on sound similarities rather than on sound equivalences; that is, paronyms prevail. Second come homonyms. Homophones are represented by only a few instances.

\section{Material selection}

The anti-proverbs discussed in this article were recorded by Anna T. Litovkina and Katalin Vargha and come from their corpus of over 7,000 Hungarian anti-proverbs, some of which have already been published in anti-proverb collections (see Litovkina \& Vargha 2005a, 2005b, 2006). While the vast majority of the sources come from the Internet, other examples were provided in 2004-2005 by students attending Anna T. Litovkina's classes on sociolinguistics and folklore at Illyés Gyula College of Education, University of Pécs (Szekszárd); these students in turn had collected the texts from their friends, relatives, and acquaintances. Additional texts were recorded by Anna T. Litovkina and Katalin Vargha from recent Hungarian newspapers, fiction, and advertisments.

\section{The focus of this article}

This article discusses one of the most frequent devices of alteration in Hungarian antiproverbs: punning. While the first and second sections address the most popular types of punning (paronyms and homonyms), the third section makes an attempt to explore some other types of puns as well (puns playing upon personal names, splitting one word into two, merging two words into one, linking puns, bilingual puns, double/triple puns, and repetitive puns) (for discussion of puns in Anglo-American, German, French, Russian and Hungarian anti-proverbs, see Litovkina et al. 2008a, 2008b; Barta et al. 2008, 2009; Hrisztova-Gotthardt et al. 2008, 2009). It must also be mentioned here that a number of the anti-proverbs fit several categories simultaneously. Such examples could be discussed in various parts of this article; as a rule, however, anti-proverbs that fit more than one category will be quoted and discussed only once. In the vast majority of anti-proverbs, punning occurs simultaneously in combination with other techniques of proverb alteration (e.g. change, addition or omission of letters or words, see Litovkina \& Vargha 2012).

\section{Paronomastic puns}

Paronomastic puns - i.e., puns involving two similar but not identical strings of sounds and graphemes - constitute by far the largest class of puns in the corpus of Hungarian antiproverbs. One of the most popular techniques of proverb alteration is distorting the basic meaning of a proverb by simply replacing a single word. The authors of anti-proverbs often try to find a word phonologically similar to one in the original proverb. For example, the selection of items substituting the word "Jóból" (of a good thing) in the proverb Jóból is megárt a sok (Too much of a good thing is harmful) is motivated by phonological convergences:

Hóból is megárt a sok. (Too much of snow is harmful)

Lóból is megárt a sok. (Too much of horse is harmful)

Sóból is megárt a sok. (Too much of salt is harmful)

Szóból is megárt a sok. (Too much of word is harmful) 


\section{European Journal of Humour Research 1(3)}

A word is frequently substituted by a similar-sounding word with a sexual connotation (for techniques of creating sexual proverb parodies and for common themes in sexual proverb variation, see Litovkina 1999a, 1999b, 2005: 87-99, 2011; on wellerisms with sexual content, see Mieder 1982):

Ahány ház, annyi szopás (So many houses, so much sucking). \{Ahány ház, annyi szokás (So many houses, so many customs) $\}[1]$

A recurring theme in the anti-proverbs is sexual intercourse itself, as illustrated by "Coito ergo sum" (Norrick 1993: 98), a parody of Descartes' famous formulation, "Cogito ergo sum." One of the favourite words for such kind of substitution is the word "kefél" (to screw). The words it substitutes on phonological basis in our corpus are "él" (to live), "fél" (to fear), and "beszél" (to speak):

Élni és kefélni (Live and let screw). \{Élni és élni hagyni (Live and let live)\}

Aki sokat alszik, keveset kefél (He who sleeps much screws little). \{Aki sokat alszik, keveset él (He who sleeps much lives little)\}

Magyar ember evés közben nem kefél (A Hungarian man does not screw while eating). \{Magyar ember evés közben nem beszél (A Hungarian man does not speak while eating)\}

Jobb kefélni, mint megijedni (It is better to screw than to get frightened). \{Jobb félni, mint megijedni (It is better to fear something than to get frightened) $\}$

A parody may twist the content of its source by a very slight distortion of its form. Of particular interest are proverb transformations in which two ideas are conjoined through the substitution, addition or omission of a single phoneme. The most frequent is the substitution of one phoneme in a word for another (most frequently consonants [2]). The most frequent position is at the beginning of the word:

A halnak is füle van (Even the fish has an ear). $\{$ A falnak is füle van (Even the wall has an ear) $\}$ Nincs új a WAP alatt. (There is nothing new under the WAP) \{Nincs új a nap alatt (There is nothing new under the sun)\}

Nem a ruha veszi az embert (It is not the clothes that buy the man). \{Nem a ruha teszi az embert (It is not the clothes that make the man)\}

Vajban ismerni meg a barátot (One can know the friend in butter). \{Bajban ismerni meg a barátot (One can know the friend in need)

Change of vowels is demonstrated in the following anti-proverbs:

A szerelöm vakít (My plumber blinds). \{A szerelem vakít (Love blinds)\}

A kivitel erősíti a szabályt (The export confirms the rule). \{A kivétel erősíti a szabályt (The exception confirms the rule)\}

In our corpus, the omission or addition of a phoneme occurs less frequently than phoneme substitution. The following examples illustrate the addition of a phoneme:

Jódból is megárt a sok (Too much of iodine is harmful). \{Jóból is megárt a sok (Too much of a good thing is harmful)\}

Trend a lelke mindennek (Trend is the soul of everything). \{Rend a lelke mindennek (Order is the soul of everything)\}

The dropping of a phoneme occurs in our material less frequently than phoneme substitution or addition: 


\section{European Journal of Humour Research 1(3)}

Amit ma megehetsz, ne halaszd holnapra (What you can eat today do not put off until tomorrow). \{Amit ma megtehetsz, ne halaszd holnapra (What you can do today do not put off until tomorrow)

There are many other types of transformations that involve one or two phonemes. A drastic change in spelling, however, by removing the resemblance between the original text of the proverb and the resultant anti-proverb, might destroy the humour of the transformation (for more, see Barta et al. 2008; Hrisztova-Gotthardt et al. 2009; Litovkina et al. 2008b).

\section{Homonymous puns}

Numerous proverbs in our material have provided good models for exploiting ambiguity through the use of a single word that is polysemous (i.e., having two meanings) or two words that are homonymous (i.e., having identical graphemic and phonemic representation). Puns of this nature are referred to in our study as homonymous puns (in our discussion we don't distinguish between polysemous and homonymous words). Certain ambiguous words have become real favourites of punsters in our material. In many cases in our corpus, the choice of a word for punning is obvious or largely predictable, as may be demonstrated in two ways: first, through the large number of proverb transformations using the word in question, and second, through the number of different proverbs that are distorted through the use of the same word.

In order to show how the use of the same punning word might give birth to many antiproverbs collected from different sources, let us observe the following alterations of the proverb Vak tyúk is talál szemet (Even a blind hen finds grain). The popularity of this proverb for this type of punning may be explained by the existence of two different connotations of the noun "tyúk" (hen and stupid woman):

\footnotetext{
Vak tyúk is talál kakast. (Even a blind hen/stupid woman finds a cock)

Vak tyúk is talál szemészt. (Even a blind hen/stupid woman finds an oculist)

Egy feltünően rövidlátó asszonyra mondta valaki: „A vak tyúk is talált férjet.” (It has been applied to a strikingly short-sighted woman: "Even a blind hen/stupid woman has found a husband")
}

Having discussed cases in which a single proverb gives rise to plentiful variations, let us now see how the popularity of certain words in the corpus of Hungarian anti-proverbs is shown through the number of punning transformations based on the same word. Consider the popularity of the word "meleg" in Hungarian anti-proverbs. Four anti-proverbs below, all of which are based on different proverbs, play on the polysemy of the word "meleg" (warm in the original proverb text vs. gay in the anti-proverbs):

\footnotetext{
Kibújik a meleg a házból (The gay leans out of the house). \{Kibújik a szeg a zsákból (The nail peeps out of the sack)\}

Addig üsd a meleget, amíg vasal (Strike the gay while he is ironing). \{Addig üsd a vasat, amíg meleg (Strike the iron while it is warm) \}

Sándor, József, Benedek, mind a hárman melegek (Sándor, József, Benedek, all three of them are gays). \{Sándor, József, Benedek, zsákban hozzák a meleget (Sándor, József, Benedek bring the warmth in a sack) $\}$ [3]

Meleg disznó a makkommal álmodik (A gay/warm pig dreams of my penis corona). \{Éhes disznó makkal álmodik (A hungry pig dreams of an acorn) $\}$
}

As shown in the four anti-proverbs above, one meaning of an ambiguous word may be risqué or indecorous. Anti-proverbs of this type, which combine a sexual meaning with a non-sexual one, represent double entendre in its strictest sense. The humour of many proverb 
transformations containing double entendres lies in the incongruous use of the vulgar or taboo word, as well as in the contrast between an innocent text of a proverb and its sexually-loaded reinterpretation. To understand the numerous puns of Hungarian sexual anti-proverbs it is essential to know an array of slang terms and euphemisms for sex organs, for masturbation, for sexual intercourse, and so on, e.g. "duda" (bagpipe or hooter vs. tits), "köcsög" (jug vs. queer), "makk" (acorn vs. penis corona), "farok" (tail vs. penis), etc.:

Éhes makkal disznókat lehet álmodni (A hungry penis corona might dream of pigs). \{Éhes disznó makkal álmodik (A hungry pig dreams of an acorn) \}

Sokat akar a farka, de nem bírja a marka (His penis wants much, but his fist [4] can’t bear it). \{Sokat akar a szarka, de nem bírja a farka (The magpie wants much, but its tail can’t stand it)\}

\section{Other types of puns}

In the two sections above we have addressed the two most frequent types of puns in Hungarian anti-proverbs, paronyms and homonyms. In this section we will explore additional types of puns in Hungarian anti-proverbs, e.g. puns playing upon personal names, splitting one word into two, merging two words into one, bilingual puns, double/triple puns, and repetitive puns.

Let us start this section with puns that play upon personal names. The surnames of famous Hungarian poets and writers, political leaders and public figures, as well as very popular Hungarian first names and surnames can be exploited for this purpose. Let us observe first "perfect" puns (or identical in sound, i.e., based on homonymy or homophony, see Hockett 1972: 157).

A number of the anti-proverbs play upon the words arany (gold) and János Arany (famous Hungarian poet, 1817-1882). For instance, in the three alterations of the proverb Nem mind arany, ami fénylik (All is not gold that glitters) below, introducing the first name of the poet ("János") as well as the word "költo"" (poet) into the context of the anti-proverbs helps us to perceive the pun:

Nem mind arany, aki János. (All is not gold/arany who is János)

Nem mind arany, aki költő. (All is not gold/arany who is a poet)

Nem mind arany, ami János. (All is not gold/arany that is János)

The three anti-proverbs below introduce the names of two other Hungarian poets into their contexts. In the first proverb transformation not only does the word "Arany" [Arany/Gold] stand for two different concepts, but the word "Tompa" does it as well (blunt vs. the surname of another famous Hungarian writer, Mihály Tompa, 1817-1868). The pun like this might be called double pun and is to be discussed below:

Nem mind Arany, ami Tompa (Not everything is Arany/Gold that is Tompa/Blunt).

The two proverb alterations below introduce the name of Sándor Petöfi (1823-most likely 1849) who was one of the key figures of the Hungarian Revolution of 1848 and who has been considered Hungary's national poet:

Nem mind arany, ami Petőfi. (Not everything is arany/gold that is Petőfi)

Hallgatni Arany, beszélni Petőfi (To be silent is Arany/Gold, to speak is Petőfi). \{Hallgatni arany, beszélni ezüst (To be silent is gold, to speak is silver) \} 


\title{
European Journal of Humour Research 1(3)
}

To appreciate the ambiguity of the following pun, we have to backtrack in our interpretation of the text of the well-known proverb: Mindenki a maga szerencséjének kovácsa (Everyone is the blacksmith of his own fortune). This proverb typically means: everyone is responsible for his fortune. When the word "Kovács" (a popular Hungarian surname) is introduced in the second part of the transformation below, just in tune with the word "kovács" (blacksmith) in the original proverb text, an anti-proverb results:

\author{
Mindenki a maga szerencséjének kovácsa. \\ Kivéve Kovács Gyulát. \\ (Everyone is the blacksmith of his own fortune. \\ Except Gyula Kovács/Blacksmith)
}

The connection between "kovács" (blacksmith) and "Kovács" (Hungarian surname) is also evoked in one of the repetitive puns discussed below.

The following proverb alteration might not even be perceived as a pun if not read:

Ha már lúd, legyen Kövér (If a goose, it should be Fat/Kövér). \{Ha már lúd, legyen kövér (If a goose, it should be fat) \}

Indeed, just after we see that the word "kövér" (fat) from the original proverb is exchanged for a word "Kövér" which starts with a capital letter, we realize that the word has probably got another meaning. Indeed, most probably this example alludes to László Kövér, a Hungarian politician, the member of FIDESZ (or the Alliance of Young Democrats).

The following two proverb mutations play on personal female names associated with flowers ("Virág" (female name) vs. "virág" (flower), and "Rózsa" female name vs. "rózsa" (rose)):

\footnotetext{
Aki a virágot szereti, az Virág nem lehet (He who loves a flower can’t be Flower/Virág). \{Aki a virágot szereti, az rossz ember nem lehet (He who loves a flower can’t be a bad man)\}

Nincsen Rózsa anyós nélkül ([No Rose/Rózsa without a mother-in-law). \{Nincsen rózsa tövis nélkül (No rose without a thorn)
}

Let us observe three "imperfect" puns (or nonidentical in sound, i.e., based on paronymy, see Hockett 1972: 157) playing on personal names. The first one refers to Péter Zwack (1927-), Hungarian businessman and diplomat, a former Hungarian ambassador to the United States (1990-1991):

Zwack vezet világtalant (Zwack leads a sightless). \{Vak vezet világtalant (A blind leads a sightless) \}

The following two proverb mutations introduce two male names into their context, "Bob" and "Botond". The choice of these names is most definitely justified by their resemblance of the word "bot" (stick) from the original proverb texts:

Isten nem ver Bobbal (God does not hit with Bob). \{Isten nem ver bottal (God does not hit with a stick)\}

A botnak két vége van, de a Botondnak csak egy (A stick has two ends but Botond has only one). \{A botnak két vége van (A stick has two ends)\}

In the repetitive pun, punning words are repeated, e.g. "korán" (early) and "Koránt" (the accusative form of the Koran):

Ki korán kel, Koránt lel (He who gets up early finds the Koran). \{ Ki korán kel, aranyat lel (He who gets 
up early finds the gold)\}

Here comes another repetitive pun based on one of the most popular surnames in the Hungarian culture discussed above, the name "Kovács":

Egy kovács nem kovács, két kovács egy kovács, azért van olyan sok Kovács (One blacksmith is not a blacksmith, two blacksmiths are one blacksmith, this is why there are so many Blacksmiths/Kovácses). \{Egy gyerek nem gyerek, két gyerek fél gyerek, három gyerek egy gyerek (One child is not a child, two children are half a child, three children are one child) \}

According to Heller (1974: 280), "[i]n theory one may have any number of puns embedded in the same utterance". In just a few anti-proverbs in our corpus, a double pun appears. At first let us discuss here some "perfect" (Hockett 1972: 157) double puns (identical in sound, i.e., based on homonyms and homophones). The following double pun is derived from the play on the word "Katalin" (day of Katalin celebrated in Hungary on 25 November vs. a female with a name Katalin) and "kopog" (it freezes vs. knocks at the door). The exchange of the second part of the proverb Karácsony locsog (at Christmas it melts) for "engedd be" (let her in) indicates that the words Katalin kopog should be perceived in a nonfigurative way:

Ha Katalin kopog, engedd be (If Katalin knocks at the door, let her in). \{Ha Katalin kopog, Karácsony $\operatorname{locsog}$ (If on the day of Katalin it freezes, at Christmas it melts)

After discussing and exemplifying perfect double puns, let us view two "imperfect" (Hockett 1972: 157) double puns (nonidentical in sound, i.e., based on paronymy):

Nem pörög a paraszt, ha nem fújja a szél (The peasant does not twirl if the wind does not blow him). \{Nem zörög a haraszt, ha nem fújja a szél (The leafage does not rustle if the wind does not blow it)\} Vas tyúk is talál szeget (Even an iron hen finds a nail). \{Vak tyúk is talál szemet (Even a blind hen finds grain)\}

Triple puns are extremely rare in our material:

Olló az ollónak nem vágja ki a szegét (Scissors do not cut out the scissors' nail). \{Holló a hollónak nem vájja ki a szemét (A raven does not pluck out a raven's eye)\}

Puns based on the mixture of words from two languages may be called bilingual puns. Bilingual puns usually employ words from two languages that are phonetically similar, or even identical, but different in meaning. As expected, in the corpus of Hungarian antiproverbs the most frequent bilingual puns are based on employing or alluding to English words or proverbs:

Aki nem Duke-ozik, az ne is egyék! (He who does not Duke [5] should not eat) \{Aki nem dolgozik, az ne is egyék (He who does not work should not eat) \}

Aki fair, az nyer (He who is fair wins). \{Aki mer, az nyer (He who ventures wins) \}

The following example is based on phonetic and graphemic similarity of words from two languages - the Hungarian word "borban" (in wine) and French "Bourbon" (European royal house, and a type of American whiskey):

„Bourbon” az igazság [Truth is in "Bourbon”]. \{Borban az igazság [Truth is in wine]\}

The following anti-proverb represents a Hungarian-Latin bilingual pun playing with a Latin 
proverb Similis simili gaudet (or its equivalent in English: Like attracts like):

Szenilis szenili gaudet. (One senile person attracts another senile person)

Certain puns involve not simply single words but groups of words. One word may be split into two (or even three). This type of pun occurs in combination with other techniques (e.g. change, addition or omission of phonemes or words):

Aki nem tud arabusul, azért egy arab se búsul (He who does not know Arabic, not a single Arab feels upset over him). \{Aki nem tud arabusul, ne beszéljen arabusul (He who does not know Arabic, should not speak Arabic) $\}$

Okos enged, ha már szenved (A man of sense allows if he already suffers). \{Okos enged, szamár szenved (A man of sense allows, an ass suffers) $\}$

In the following example two words are merged into one (i.e., "remény hal" (hope dies) becomes "reményhal" (hope fish), just in tune with the word "lepényhal" (flounder)). This technique of punning is less frequent than the previous one:

A lepényhal megy elöször, a reményhal meg utoljára (The flounder goes first, the hope fish goes last). \{A remény hal meg utoljára (Hope dies last)\}

Let us finish this section with the so called "linking pun", following Esar's terminology (Esar 1952: 78):

Messziről jött ember azt mond, ami takar (The man who has come from far away says what covers (it)). \{Messziről jött ember azt mond, amit akar (The man who has come from far away says what he wants)\}

While in the original proverb text, the word "amit" (what) ends with a consonant and is followed by the word "akar" (wants) beginning with a vowel, in the anti-proverb above the marker of the accusative " $\mathrm{t}$ " changes its position, and wanders from the end of one word to the beginning of the other, coining the following combination "ami takar" (what covers (it)), in which the first word starts with a vowel and the second begins with a consonant.

Many more types of punning could be addressed in this article but we must come to a conclusion now.

\section{Conclusions}

This article has focused on Hungarian anti-proverbs (deliberate proverb innovations). The most frequent types of punning (e.g. paronyms and homonyms) as well as some other types of punning (puns playing upon personal names, bilingual puns, double/triple puns, linking puns, and repetitive puns) were discussed and demonstrated here. Since proverbs are considered sacrosanct by many of us, their reinterpretation in innovative ways can create humour. We laugh at some anti-proverbs because they skew our expectations about traditional values, order, and rules. We are, however, sometimes struck by the absurdity of some situations portrayed in proverb parodies, especially when they rely purely upon linguistic tricks employed for the sole purpose of generating play forms and of making punning possible. Puns have been frequently attacked as being "the lowest form of wit", especially in Englishspeaking communities. Raskin (1985: 116) points out that "[if] the trigger is there but the scripts and the oppositeness relation are not, the pun remains an artificial, low-quality product". Punsters, however, more often than not play in unsophisticated ways with the 
sounds of words, but not with their meanings. Proverbs very frequently lend themselves to manipulation exclusively for the sake of manipulation. Indeed, in many cases in our corpus, the choice of a word for punning is obvious or largely predictable. The vast majority of puns in our material are based on purely phonetic and not semantic relations between words. Nevertheless, the similarity between the original words and their substitutes makes some distortions funny, even if they are based on pure accidental resemblances in sounds and not in meanings.

\section{Notes}

[1] For the reader's convenience all anti-proverbs in this chapter are followed by their original forms, given in \{\} brackets. All Hungarian proverbs and anti-proverbs are followed by their translations into English, given in () brackets.

[2] It might be connected with a number of vowels and consonants.

[3] This Hungarian proverbial saying refers to the days of three saints in March (18th - Sándor, 19th József, and $21 \mathrm{st}$ - Benedek).These saints are said to "bring the warmth in a sack", that is, the weather usually gets warmer at this time of the year.

[4] This example might also allude to masturbation.

[5] Referring to a computer game.

\section{References}

Attardo, S. (1994). Linguistic Theories of Humor. Berlin: Mouton de Gruyter.

Barta, P., Litovkina, A. T., Hrisztova-Gotthardt, H. \& Vargha, K. (2008). 'Paronomázia az antiproverbiumokban - magyar, angol, német, francia és orosz példákkal' [Paronomasia in Hungarian, English, German, French and Russian anti-proverbs], in M. Daczi, A. T. Litovkina \& P. Barta (eds.), Ezerarcú humor. Az I. Magyar Interdiszciplináris Humorkonferencia elöadásai, Budapest: Tinta Könyvkiadó, pp. 83-97.

Barta, P., Litovkina, A. T., Hrisztova-Gotthardt, H. \& Vargha, K. (2009). 'Polysémie, homonymie et homophonie dans les proverbes détournés - avec des exemples français, hongrois, anglais, allemands et russes' [Polysemy, homonymy and homophony in antiproverbs - with French, Hungarian, English, German and Russian examples]. Acta Ethnographica Hungarica, 54 (1), pp. 63-75.

Esar, E. (1952). The Humor of Humor. New York: Horizon Press.

Freud, S. (1960 [1905]). Jokes and Their Relation to the Unconscious. Trans. Strachey, J. New York: W. W. Norton \& Company, Inc.

Heller, L. G. (1974). 'Toward a general typology of the pun'. Language and Style, 7 (4), pp. 271-282.

Hockett, Ch. F. (1972). 'Jokes', in M. E. Smith (ed.), Studies in Linguistics in Honor of George L. Trager, The Hague: Mouton, pp. 153-178.

Hrisztova-Gotthardt, H., Litovkina, A. T., Barta, P. \& Vargha, K. (2008). 'Poliszémia, homonímia és homofónia az antiproverbiumokban - magyar, angol, német, francia és orosz példákkal' [Polysemy, homonymy and homophony in Hungarian, English, German, French and Russian anti-proverbs], in M. Daczi, A. T. Litovkina \& P. Barta (eds.), Ezerarcú humor. Az I. Magyar Interdiszciplináris Humorkonferencia elöadásai, Budapest: Tinta Könyvkiadó, pp. 98-108. 
Hrisztova-Gotthardt, H., Litovkina, A. T., Vargha, K. \& Barta, P. (2009). 'Paronomasie oder wie ein Sprichwort zum Antisprichwort wird' [Paronomasia or how a proverb is transformed into an anti-proverb]. Acta Ethnographica Hungarica, 54 (1), pp. 77-94.

Koestler, A. (1964). The Act of Creation. New York: The Macmillan Company.

Litovkina, A. T. (1999a). "If you are not interested in being healthy, wealthy and wise - how about early to bed?": Sexual proverb transformations'. Semiotische Berichte mit Linguistik Interdisziplinär, 23 (1/4) (Special issue: Sex and the Meaning of Life / Life and the Meaning of Sex), pp. 387-412.

Litovkina, A. T. (1999b). 'Spare the rod and spoil the child: Sexuality in proverbs, sayings and idioms'. Proverbium: Yearbook of International Proverb Scholarship, 16, pp. 141-165.

Litovkina, A. T. (2005). Old Proverbs Cannot Die: They Just Fade into ParoDY: AngloAmerican Anti-Proverbs. Budapest: Eötvös Loránd University Habilitation thesis.

Litovkina, A. T. (2011). 'Sexuality in Anglo-American anti-proverbs', in M. Dynel (ed.), The Pragmatics of Humour across Discourse Domain, Amsterdam: John Benjamins, pp. 191-213.

Litovkina, A. T., Barta, P., Hrisztova-Gotthardt, H. \& Vargha, K. (2008a). 'A szójáték egyes típusai az antiproverbiumokban - magyar, angol, német, francia és orosz példákkal' [Various types of wordplay in Hungarian, English, German, French and Russian antiproverbs], in M. Daczi, A. T. Litovkina \& P. Barta (eds.), Ezerarcú humor. Az I. Magyar Interdiszciplináris Humorkonferencia elöadásai, Budapest: Tinta Könyvkiadó, pp. 109122.

Litovkina, A. T, Vargha, K., Barta, P. \& Hrisztova-Gotthardt, H. (2008b). 'Punning in AngloAmerican, German, French, Russian and Hungarian anti-proverbs'. Proverbium: Yearbook of International Proverb Scholarship, 25, pp. 249-288.

Litovkina, A. T. \& Vargha, K. (2005a). "Éhes diák pakkal álmodik": Egyetemisták közmondás-elváltoztatásai [“A Hungry Student Dreams about a Parcel”: Twisted Proverbs of Students]. Budapest: Private publication.

Litovkina, A. T. \& Vargha, K. (2005b). "Viccében él a nemzet”: Magyar közmondás-paródiák ["The Nation lives in its Jokes": Hungarian Proverb Parodies]. Budapest: Private publication.

Litovkina, A. T. \& Vargha, K. (2006). "Viccében él a nemzet”: Válogatott közmondásparódiák ["The Nation lives in its Jokes": Selected Proverb Parodies]. Budapest: Nyitott Könyvmühely.

Litovkina, A. T. \& Vargha, K. (2012). 'The most common types of alteration in Hungarian anti-proverbs', in A. T. Litovkina, J. Sollosy, P. Medgyes \& W. Chłopicki (eds.), Hungarian Humour, Cracow: Tertium Society for the Promotion of Language Studies, pp. 287-315.

Mieder, W. (1982). 'Sexual content of German wellerisms'. Maledicta, 6, pp. 215-223.

Milner, G. B. (1972). 'Homo ridens: towards a semiotic theory of humour and laughter'. Semiotica, 5 (1), pp. 1-30.

Nilsen, D. L. F. (1989). 'Review of J. Culler (ed.) (1988). On Puns: The Foundation of Letters. London: Basil Blackwell'. Humor: International Journal of Humor Research, 2 (4), pp. 397-400.

Norrick, N. R. (1993). Conversational Joking: Humor in Everyday Talk. Bloomington: Indiana University Press.

Raskin, V. (1985). Semantic Mechanisms of Humor. Dordrecht: Reidel.

Webster's New Universal Unabridged Dictionary. (2nd ed.). n. p.: Dorset \& Baber. 